\title{
Cold-induced vasodilation during continuous exercise in the extreme cold air $\left(-30.6{ }^{\circ} \mathrm{C}\right)$
}

\author{
Chuansi Gao ${ }^{1 *}$, Li-Yen Lin², Amitava Halder ${ }^{1}$, Kalev Kuklane ${ }^{1}$ \\ From 15th International Conference on Environmental Ergonomics (ICEE XV) \\ Portsmouth, UK. 28 June - 3 July 2015
}

\section{Introduction}

Cold induced vasodilation (CIVD) in previous studies was mostly evoked by cold water immersion at 0,5 , and $8{ }^{\circ} \mathrm{C}$ of the upper or lower extremities without performing physical work [1]. A limited number of investigations incorporated intermittent exercises during cold air exposure [2]. Literature has documented that the CIVD occurrence depended on the body core temperature [2], [3]. It was observed that CIVD in cold water immersion was highly variable across the fingers and was not a generalizable response across fingers or toes [4]. However, the number of studies on cold air induced vasodilation in the extremely cold is limited. The objective of this study was to investigate individual variations of finger CIVD in relation to the core and mean skin temperatures during continuous exercise in the extreme cold air $\left(-30.6{ }^{\circ} \mathrm{C}\right)$.

\section{Methods}

Four young and healthy male subjects wore cold protective clothing ensemble $\left(I_{c l}=1.89 \mathrm{clo}\right)$ and walked at $4 \operatorname{MET}\left(232.8 \mathrm{~W} / \mathrm{m}^{2}\right)$ on a treadmill in a climatic chamber $\left(T_{a}=-30.6 \mathrm{C}, V_{a}=0.4 \mathrm{~m} / \mathrm{s}\right)$ for $90 \mathrm{~min}$ [5]. Hestra wind stopper fleece fabric gloves (relatively thin) were used. The core and skin temperatures were measured respectively in the rectum $10 \mathrm{~cm}$ above the anal sphincter, and on the forehead and left side of the body on the upper arm, forearm, hand, little finger, chest, scapula, thigh, calf, and little toe. The mean skin temperature $\left(T_{s k}\right)$ was calculated below.

$T s k=0.07\left(T_{-}\right.$forehead $+T_{-}$upperarm $+T_{-}$forearm $)+0.175\left(T_{-}\right.$chest $+T_{-}$scapula $)+0.05 T$ hand $+0.19 T_{-}$thigh $+0.20 T_{-}$calf

\footnotetext{
* Correspondence: Chuansi.Gao@design.lth.se

'Thermal Environment Laboratory, Division of Ergonomics and Aerosol Technology, Department of Design Sciences, Faculty of Engineering, Lund University, Box 118, 22100 Lund, Sweden

Full list of author information is available at the end of the article
}

\section{Results}

CIVD in the little finger occurred when the subjects' rectal temperatures $\left(\mathrm{T}_{\mathrm{re}}\right)$ were relatively stable in the range of $37.1-38.1{ }^{\circ} \mathrm{C}$ and the $\mathrm{T}_{\mathrm{sk}}$ in the range of $32.0-25.3^{\circ} \mathrm{C}$. Within these ranges, the finger CIVD periodical responses were not dependent on the $T_{\text {re }}$ and $\mathrm{T}_{\text {sk }}$ changes. The onset time, $\mathrm{T}_{\min }, \mathrm{T}_{\max }$ and $\mathrm{T}_{\text {finger_mean }}$, amplitude $\left(\mathrm{T}_{\max }-\mathrm{T}_{\text {min }}\right.$ ), frequency (number of waves) of the CIVD were $14.6(3.5) \mathrm{min}, 3.8(3.4){ }^{\circ} \mathrm{C}, 16.5(3.6){ }^{\circ} \mathrm{C}$, $7.9(1.4){ }^{\circ} \mathrm{C}, 12.7(4.4){ }^{\circ} \mathrm{C}, 7.5$ (4.7) respectively.

\section{Discussion}

The finger CIVD appeared in all four subjects. However, the onset time, minimum, maximum and mean finger temperatures, amplitude, frequency of the CIVD varied among the four subjects. The finger CIVD occurred when the mean finger temperatures of the four subjects were below $10{ }^{\circ} \mathrm{C}$, thus it seems to be related to the local cooling of the extremities during continuous and stable exercise at high metabolic rate in the extremely cold environment. The CIVD in toes was not as clear as in the fingers, which might be attributed to the continuous walking.

\section{Conclusion}

The finger CIVD varies among the subjects. Its occurrence is not dependent on $\mathrm{T}_{\mathrm{re}}$ and $\mathrm{T}_{\mathrm{sk}}$ changes within the $\mathrm{T}_{\text {re }}$ and $\mathrm{T}_{\text {sk }}$ ranges $\left(37.1-38.1{ }^{\circ} \mathrm{C}\right.$ and $32.0-25.3^{\circ} \mathrm{C}$ ), but it is associated with the local cooling of the extremities during continuous $90 \mathrm{~min}$ walking at $4 \mathrm{MET}$ in the extreme cold air $\left(-30.6{ }^{\circ} \mathrm{C}\right)$.

\footnotetext{
Authors' details

'Thermal Environment Laboratory, Division of Ergonomics and Aerosol Technology, Department of Design Sciences, Faculty of Engineering, Lund University, Box 118, 22100 Lund, Sweden. 'Department of Testing and Certification, Taiwan Textile Research Institute (TTRI), 6 Chengtian Road, Tucheng District, New Taipei, 23674, Taiwan.
} 


\section{References}

1. Daanen HAM: Eur J Appl Physiol 2003, 89:411-426.

2. Flouris AD, Westwood DA, Mekjavic IB, Cheung SS: Eur J Appl Physiol 2008, 104:491-499.

3. Daanen HAM, Wammes $\perp A$, Lotens WA: Proceedings of the fifth international conference Environmental Ergonomics. Maastricht 1992, 222-223.

4. Cheung SS, Mekjavic IB: Eur J Appl Physiol 2007, 99:701-705.

5. Gao C, Lin L, Halder A, Kuklane K, Holmér I: Applied Ergonomics 2015, 46:44-53.

doi:10.1186/2046-7648-4-S1-A58

Cite this article as: Gao et al: Cold-induced vasodilation during

continuous exercise in the extreme cold air $\left(-30.6^{\circ} \mathrm{C}\right)$. Extreme Physiology \& Medicine 2015 4(Suppl 1):A58.

Submit your next manuscript to BioMed Central and take full advantage of:

- Convenient online submission

- Thorough peer review

- No space constraints or color figure charges

- Immediate publication on acceptance

- Inclusion in PubMed, CAS, Scopus and Google Scholar

- Research which is freely available for redistribution

Submit your manuscript at www.biomedcentral.com/submit
() Biomed Central 